\title{
Рання хірургічна тактика при постінфарктних розривах міжшлуночкової перегородки
}

\author{
Мороз В. С. ${ }^{1}$, Орищин Н. Д. ${ }^{1,2}$, Павлик С. С. ${ }^{1}$, Кушта О. Ю. ${ }^{1}$, Титюк В. А. ${ }^{1}$, Куртяк 3. 3. ${ }^{1}$ \\ 1 Львівський обласний кардіологічний центр \\ 2 Львівський національний медичний університет імені Данила Галицького
}

\begin{abstract}
Розриви міжшлуночкової перегородки (МШП) є причиною до 5\% смертей у ранньому періоді інфаркту міокарда (IM). Хірургічне лікування в ранньому періоді ІМ поєднане з високим ризиком, однак дозволяє зменшити смертність пацієнтів.
\end{abstract}

Мета роботи - проаналізувати перебіг післяінфарктного розриву МШП та ефективність хірургічного лікування під час гострого періоду IM.

Матеріали та методи дослідження. У 5 пацієнтів Львівського обласного кардіологічного центру в гострому періоді ІМ виконали пластику МШП з приводу розриву. Діагноз встановлено методом ехокардіографії. Операцією вибору була пластика МШП методом виключення інфаркту за David. Час від початку IM до операції склав від 1 до 5 діб. Один пацієнт помер унаслідок поліорганної недостатності, інші четверо одужали і перебувають під наглядом від 11 до 36 місяців. У трьох випадках на 1-2-й день після операції у пацієнтів виявили резидуальне шунтування по краю латки, яке не потребувало повторної операції.

Висновки. Пластика розривів МШП у гострому періоді IM за методом David є виправданою і має позитивний результат. Ехокардіографія $є$ методом діагностики розривів МШП і резидуального шунтування.

Ключові слова: інфаркт міокарда, розрив міжшлуночкової перегородки, ехокардіографія, пластика міжшлуночкової перегородки.

Розрив міжшлуночкової перегородки (МШП) - одне з найбільш серйозних ускладнень гострого інфаркту міокарда, яке може стати фатальним. Розриви МШП стаються у 1-2\% пацієнтів із гострим інфарктом міокарда (ГІМ) без проведення тромболізису, до $0,2 \%$ - у пацієнтів із виконаною реперфузією і є причиною до $5 \%$ смертей у ранньому періоді IM [1]. У більшості випадків розриви відбуваються в перші 2-7 днів від початку ГІМ. Хірургічне лікування в ранньому періоді IM поєднане з високим операційним ризиком, однак дає можливість удвічі зменшити смертність порівняно з медикаментозним лікуванням у таких пацієнтів. Операційна тактика виключення зони інфаркту дозволяє покращити результати хірургічного лікування, проте результат лікування залежить від функціонального стану пацієнта на момент операції. Наводимо аналіз перебігу післяінфарктного розриву МШП при застосуванні пластики в ранньому періоді на прикладі 5 пацієнтів Львівського обласного кардіологічного центру.

Мета роботи - проаналізувати перебіг післяінфарктного розриву МШП та ефективність хірургічного лікування під час гострого періоду IM.

Матеріали та методи дослідження. Ретроспективно проаналізували клінічні випадки 5 пацієнтів Львівського обласного кардіологічного центру, яким у гострому періоді IM (до 5 днів від початку IM) виконали пластику МШП з приводу розриву. За 2013-2016 pp. у відділенні кардіохірургії Львівського обласного державного клінічного лікувально-діагностичного кардіологічного центру було прооперовано 5 пацієнтів (4 жінки і 1 чоловік) із розривом міжшлуночкової перегородки внаслідок гострого IM. Всім пацієнтам розрив МШП було діагностовано методом ЕхоКГ з доплерографією. Операцією вибору у даних пацієнтів була пластика МШП методом виключення зони інфаркту за David (infarct exclusion technique). Проводився аналіз часового проміжку від початку ГІМ до розриву МШП, часу від настання гострого розриву МШП до початку операції, часу від початку IM до операції, результатів коронаро-ангіографії, ехокардіографії, біохімічних показників (зокрема, креатиніну як критерію гострої ниркової недостатності) та результатів хірургічного лікування.

Результати досліджень та їх обговорення. Середній вік пацієнтів становив $68 \pm 5$ років. У трьох пацієнтів в анамнезі була гіпертонічна хвороба. У двох із п'яти пацієнтів із гострим розривом МШП останній стався на тлі тромболітичної терапії, виконаної на 3-6-ту годину хвороби, в обох випадках засобом виконання тромболізису була стрептокіназа. У 2 випадках пацієнти поступили до стаціонару вже з ускладненим IM, на тлі якого виник розрив МПШ. Клінічним проявом у всіх 
пацієнтів було виникнення грубого систолічного шуму вздовж лівого краю грудини, у 2 пацієнтів, які поступили до клініки з попередньо виниклим розривом, спостерігалися симптоми лівошлуночкової серцевої недостатності

Середній час до виникнення розриву становив $30 \pm 11$ годин (1 добу). У пацієнтів, яким виконали тромболізис, час до виникнення розриву був 7 год. і 46 год. (до 2 діб), у пацієнтів без тромболізису - 1,5 доби. У 2 пацієнтів спостерігалися ознаки кардіогенного шоку 1 ступеня. Інфаркт міокарда у 4 пацієнтів - передньої локалізації, в басейні лівої коронарної артерії, в одного пацієнта - нижній IM, оклюзія правої коронарної артерії. В одного пацієнта при коронарографії виявили трисудинне ураження коронарного русла, у 3 пацієнтів - проксимальні оклюзії однієї судини, в одного пацієнта - міокардіальний місток; інфаркт, ймовірно, зумовлений тромбозом артерії (табл. 1).

Діагноз у всіх випадках запідозрили на основі виявлення грубого систолічного шуму вздовж лівого краю грудини. Встановили діагноз розриву перегородки способом ехокардіографії з кольоровою доплерографією. Дефект локалізувався в ділянці верхівки в 4 випадках (рис. 1), в одному випадку (при нижньому IM) дефект мав спіралеподібну форму. В однієї пацієнтки розрив МШП був поєднаний із «прикритим» зовнішнім розривом правого шлуночка (ПШ) і гемоперикардом (розрив МШП локалізувався безпосередньо поблизу

Таблиця 1

Клінічні дані та результати інструментального обстеження пацієнтів із післяінфарктними розривами МШП

\begin{tabular}{|c|c|c|c|c|c|}
\hline & Пацієнт 1 & Пацієнт 2 & Пацієнт 3 & Пацієнт 4 & Пацієнт 5 \\
\hline Вік & 74 & 70 & 61 & 75 & 60 \\
\hline Стать & ж & ж & M & ж & ж \\
\hline Гіпертонічна хвороба & 2 & 2 & 0 & 2 & 0 \\
\hline Локалізація IM & передній & передній & нижній & передній & передній \\
\hline Стеноз LAD & $95 \%$ & $100 \%$ & 0 & 0 & $100 \%$ \\
\hline Стеноз СX & $90 \%$ & 0 & 0 & 0 & 0 \\
\hline Стеноз RCA & 0 & 0 & $100 \%$ & 0 & 0 \\
\hline Стеноз Diag & $90 \%$ & 0 & 0 & 0 & 0 \\
\hline Багатосудинне ураження & так & - & - & - & - \\
\hline Тромболізис, час до виконання & $\begin{array}{l}3 \text { год. } 40 \text { хв., } \\
\text { стрептокіназа }\end{array}$ & - & - & - & $\begin{array}{l}\text { 6-та година, } \\
\text { стрептокіназа }\end{array}$ \\
\hline Час від поч. ІМ до розриву & 7 год. & 1 доба & 1 доба & 2 доби & 2 доби \\
\hline Час від початку IM до операції & 30 год. & 1 доба & 2 доби & 5 діб & 3,5 доби \\
\hline $\begin{array}{l}\text { Час від розриву МШП до } \\
\text { операції }\end{array}$ & 23 год. & 6 год. & 1 доба & 3 доби & 1,5 доби \\
\hline AТ сист., мм рт. ст. & $90-80$ & 90 & 125 & 100 & $110-100$ \\
\hline АТ діаст., мм рт. ст. & 50 & 50 & 80 & 60 & $80-70$ \\
\hline Шок до опер. & так & так & - & - & - \\
\hline Добутамін & так & так & - & - & так \\
\hline Протеїнурія & так & - & - & - & - \\
\hline Креатинін, мкмоль/л & 470 & 165 & 114 & 88 & 99,7 \\
\hline Діаметр дефекту за ЕхоКГ, мм & 14 & 9 & 18 & 14 & 14 \\
\hline КДР ЛШ, мм & 47 & 53 & 44 & 50 & 41 \\
\hline Стінки, мм & $16 / 12$ & $16 / 12$ & $11 / 10$ & $14 / 14$ & $11 / 11$ \\
\hline ФВ ЛШ, \% & 55 & 70 & 68 & 65 & 40 \\
\hline КДР ПШ, мМ & 28 & 19 & 23 & 26 & 23 \\
\hline Операція & $\begin{array}{c}\text { АКШ + пластика } \\
\text { мШП }\end{array}$ & $\begin{array}{l}\text { Пластика } \\
\text { МШП }\end{array}$ & $\begin{array}{c}\text { АКШ + пластика } \\
\text { мШП }\end{array}$ & Пластика МШП & $\begin{array}{c}\text { АКШ + пластика } \\
\text { МШП }\end{array}$ \\
\hline Результат & померла & одужала & одужав & одужала & одужала \\
\hline Примітки & & $\begin{array}{l}\text { решунт } \\
4 \text { мм }\end{array}$ & $\begin{array}{l}\text { решунт } \\
4 \text { мм }\end{array}$ & $\begin{array}{l}\text { пластика вільної } \\
\text { стінки ПШ }\end{array}$ & $\begin{array}{l}\text { решунт } 8 \text { мм, } \\
\text { СН2Б-A }\end{array}$ \\
\hline Тривалість нагляду & - & 31 міс. & 29 міс. & 15 мiс. & 11 міс. \\
\hline
\end{tabular}

КДР - кінцево-діастолічний розмір, ФВ - фракція викиду 


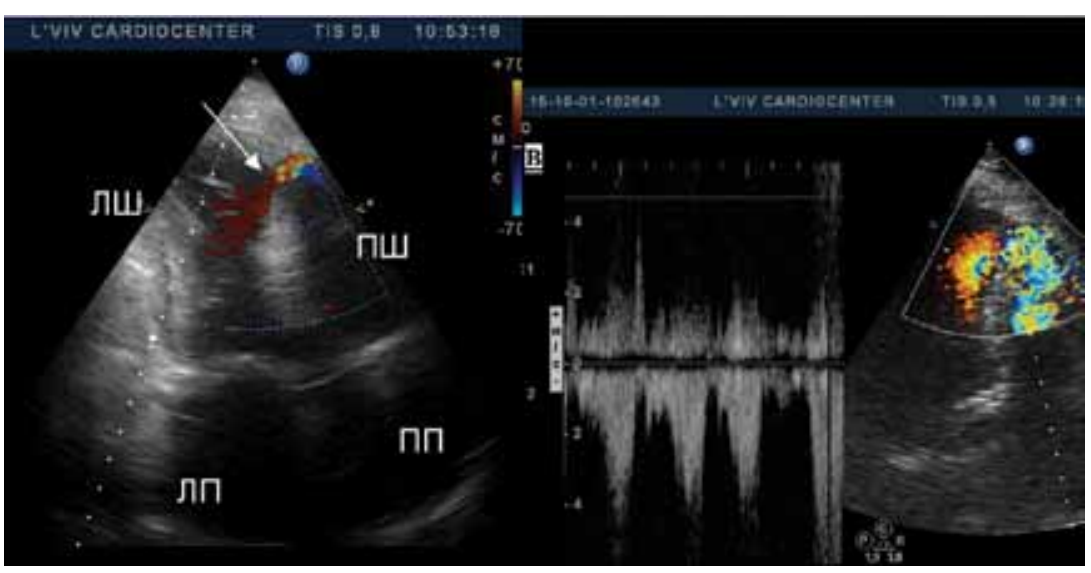

Рис. 1. Верхівкова 4-камерна проекція. Післяінфарктний дефект МШП поблизу верхівки (стрілка). В. Кольорова доплерографія (справа). Турбулентний потік високої швидкості у правому шлуночку верхівки серця). При доплерографії в усіх випадках реєстрували потік крові через дефект з лівого у ПШ. Розмір лівого шлуночка (ЛШ) був збережений $(47 \pm 3$ мм), фракція викиду ЛШ була помірно зниженою в одного пацієнта, збереженою в усіх інших пацієнтів. У трьох із п’яти пацієнтів виявили ознаки тривалої гіпертонії гіпертрофію стінок ЛШ. Дилатація правого шлуночка як прояв перевантаження виявлена лише в одного пацієнта (табл. 1).

Усім пацієнтам виконали пластику за методикою David (техніка виключення зони інфаркту - infarct exclusion technique) [6]. У трьох випадках пластику МШП поєднували 3 операцією аортокоронарного шунтування. Метод пластики МШП полягав у накладанні широкої лати з перикарда, яка виключала територію некротизованої МШП і була пришита в межах здорових тканин. Складність операції полягає у визначенні межі неуражених тканин в умовах гострого IM. Термін виконання операції - від кількох годин до 3 діб після розриву. Час від початку IM до операції від 1 до 5 діб. Один пацієнт помер на 7-му добу після операції при наявності симптомів поліорганної недостатності (пацієнт 1, на момент діагностики розриву МШП наявне перевантаження і дисфункція правого шлуночка, ниркова недостатність). Пацієнти, які одужали, перебувають під наглядом. Тривалість нагляду після операції - від 11 до 36 місяців (табл. 1). У трьох випадках пластики на 1-2-й день від операції у паці- єнтів виявили резидуальне шунтування по краю латки. Решунт запідозрили при аускультації нововиниклого систолічного шуму після операції, діагноз встановили за допомогою ехокардіографії з кольоровою доплерографією (рис. 2). Розмір резидуального шунта - від 4 до 8 мм, у 2 хворих скид крові гемодинамічно незначущий, в однієї хворої призводив до перевантаження правого шлуночка і правошлуночкової недостатності.

Обговорення. Незважаючи на прогрес у лікуванні ГІМ, частота постінфарктних розривів МШП залишається стабільною протягом останніх десятиліть, а смертність при цих ускладненнях є високою і сягає 19-53\% [5, 7]. Післяінфарктні розриви МШП є серйозним викликом для кардіохірургів, оскільки йдеться про операцію в умовах вираженої міомаляції та слабості міокарда лівого шлуночка.

Розрив перегородки звичайно настає внаслідок трансмурального коагуляційного некрозу із стоншенням стінки. Розрив перегородки може ускладнювати IM будь-якої локалізації: для передніх ІМ характерні розриви поблизу верхівки ЛШ, для нижніх IM - на межі базального та середнього сегментів [4, 9, 10]. Розриви МШП можуть мати просту і складну анатомічну будову. Гострий дефект перегородки призводить до шунтування потоку крові із лівого у правий шлуночок, об'ємного перевантаження обох шлуночків і легеневої артерії й, відповідно, до дисфункції правого шлуночка, легеневої гіпертензії.

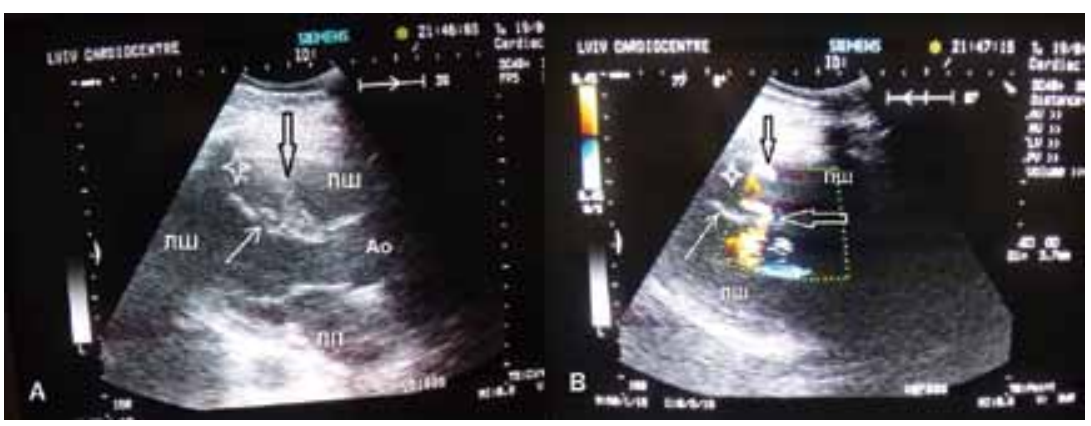

Рис. 2. Ехокардіографічні ознаки резидуального шунта по краю латки. A: чорна стрілка - міжшлуночкова перегородка, біла стрілка - латка з дефектом по краю, астериск - камера між латкою і міжшлуночковою перегородкою. B: широка біла стрілка - турбулентний потік при кольоровій доплерографії через дефект по краю латки в камеру між латкою і МШП 
Діагностика післяінфарктних розривів МШП полягає у ехокардіографічному виявленні шунтуючого потоку з лівого у правий шлуночок і безпосередньому виявленні дефекту МШП. Ця діагностика часто утруднена через складну анатомію дефекту: хід його в частині випадків спіральний, неправильний, вхідний і вихідний отвори розташовані в різних площинах. При ехокардіографії визначають розміри дефекту, об'єм скиду крові (співвідношення Qp до Qs). У пацієнтів із невеликими дефектами, у яких планують відтерміновану хірургію, моніторують тиск у легеневій артерії та функцію правого шлуночка: наростання легеневої гіпертензії та дисфункція правого шлуночка вказують на необхідність ургентного втручання. Ехокардіографія $\epsilon$ інструментом спостереження за пацієнтами в післяопераційному періоді з метою виявлення резидуальних шунтів, оцінки їх значення, оцінки функції шлуночків серця.

Лише хірургічна пластика дефекту може запобігти прогресуванню серцевої недостатності та фатальному перебігу хвороби. Тактика хірургії розривів МШП зазнала значної еволюції впродовж останніх десятиліть. Якщо до 1990-х років кардіохірурги дотримувалися вичікувальної тактики для того, щоб пришивати лату в умовах добре фіброзованих країв дефекту, то в останні десятиліття поширена тактика раннього хірургічного втручання методом «виключення» зони інфаркту (широка перикардіальна лата, яку пришивають у межах не уражених інфарктом тканин) [6]. Такий спосіб дозволяє виконувати операцію в умовах наявної міомаляції в зоні інфаркту, оскільки шви накладають на відстані від вогнища некрозу. Цей спосіб застосували в усіх випадках пластики у пацієнтів нашого центру.

Пошук оптимального способу пластики МШП при постінфарктних розривах триває. Так, група хірургів з Shiga University of Medical Science (Otsu, Японія) запропонувала техніку латки «розширений сандвіч», яку застосовували в ранньому терміні IM і отримали добрі результати трирічного виживання (76\%), рання смертність була подібною до групи David $(20 \%)[3,8]$. Техніка «extended sandwich patch technique», як і спосіб David, передбачає виключення зони некрозу. Ми використали спосіб David як найбільш прийнятний для операції в ранньому періоді IM в умовах міомаляції, що, на відміну від способу Hosoba [3, 8], не передбачає розрізу правого шлуночка, який може спричинити правошлуночкову дисфункцію.

На даний час немає одностайного підходу до терміну виконання хірургічної пластики післяінфарктного розриву перегородки. Частина кардіохірургів обстоює тактику ургентної операції, інша частина вважає, що більш успішними є втручання після 7-го дня від початку IM [1] і навіть після 21 дня від початку IM [13]. У вітчизняній літературі ми виявили лише одне пові- домлення про операції пластики постінфарктних розривів МШП, де термін від початку IM до операції становив від 12 до 360 днів [1]. Прихильниками раннього втручання були група Pang зі співавторами, які виконували пластику у перші 9 годин після діагностики розриву [10], та David із співавторами (80\% пацієнтів оперували в термін до 7 днів, 16\% пацієнтів - від 8 до 21 доби) [6].

Слід зауважити, що низьку операційну смертність після 21 дня від початку IM можна пояснити природним відбором: пацієнти більшого ризику або були прооперовані раніше за життєвими показаннями, або померли до операції. Так, за результатами дослідження GUSTO-I, 30-денна смертність прооперованих пацієнтів становила 47\% (середній термін виконання операції - 3,5 дні від початку IM), неоперованих пацієнтів 94\% [7]. Хоча операційна смертність при пластиці післяінфарктних розривів дуже висока, проте без операції вона майже вдвічі вища. Серед пацієнтів групи Poulsen, у яких виконали операцію, 30-денне виживання становило $71 \%$, річне виживання - 48\%, 5-річне виживання - 32\%. Серед пацієнтів, яких лікували медикаментозно, 30-денна смертність становила 100\% [11].

Ризик операції частково пов'язаний з імовірністю післяопераційної систолічної дисфункції ЛШ в умовах гострого IM, частково - з проблемами хірургічної техніки (часто важко розпізнати чітко краї зони некрозу, а шви на некротичних тканинах призводять до рецидиву дефекту). Одним з ускладнень операції в гострому періоді IM є резидуальні шунти по краю латки: їх частота, за даними літератури, становить від 28 до 43\%, а потреба в реоперації з цього приводу - 10\% [8]. Серед наших пацієнтів у 3 стався резидуальний шунт, однак у двох пацієнтів він не мав гемодинамічного значення, в третьої пацієнти застосована медикаментозна корекція. Градієнт тиску між лівим і правим шлуночками «гамується» в камері між латкою і МШП, навантаження на правий шлуночок відповідно не є значним.

У більшості наших пацієнтів до операції показники гемодинаміки були стабільними (крім пацієнта 1). Це можна пояснити втручанням у ранні терміни після розриву. Всі були прооперовані в гострому періоді IM до 7 дня від початку хвороби (тобто у час, пов'язаний із найбільшим ризиком для операції, в умовах максимальної міомаляції та високої ймовірності серцевої слабості). Середній час від початку IМ до операції становив від 1 до 5 діб, від розриву МШП до операції від кількох годин до 3 діб. Перевагою пацієнтів даного дослідження була збережена фракція викиду ЛШ, відсутність вираженої дисфункції ЛШ у всіх пацієнтів, крім однієї (пацієнтка померла), відсутність ниркової недостатності на момент операції в усіх пацієнтів (крім пацієнта 1). Пацієнти, які одужали, перебувають під наглядом від 11 до 31 місяців, більшість перебуває у II 
функціональному класі. У померлої пацієнтки було багатосудинне ураження коронарного русла, явища ниркової недостатності до операції, дефект був великим і швидко призвів до перевантаження ПШ і застійної $\mathrm{CH}$.

Висновки. Досвід хірургічного лікування післяінфарктних розривів МШП у Львівському кардіологічному центрі свідчить про те, що їх хірургічне лікування в гострому періоді IM (до 7 днів) виправдане і має позитивний результат. Ехокардіографія є доступним методом діагностики розривів МШП, їх локалізації, величини, гемодинамічного значення, а також методом діагностики післяопераційних ускладнень (резидуальне шунтування). Решунтування по краю лати є частим ускладненням операції в гострому періоді IM, однак у більшості випадків воно не потребує повторного хірургічного втручання, оскільки не призводить до перевантаження камер серця.

Перспективи подальших досліджень. Пластика МШП при післяінфарктних розривах під час гострого періоду ІМ вимагає подальшого вдосконалення техніки операції, анестезіологічного та реанімаційного забезпечення. У подальших дослідженнях потрібно проаналізувати більшу кількість пацієнтів для визначення факторів, які впливають на прогноз пацієнта. Необхідний тривалий нагляд за пацієнтами після пластики МШП з аналізом впливу показників лабораторно-інструментальних досліджень на прогноз пацієнтів.

\section{Література}

1. Післяінфарктний розрив міжшлуночкової перегородки: частота розвитку, результати хірургічного лікування / Урсуленко В. І., Руденко А. В., Захарова В. П. та ін. // Серце і судини. - 2014. - № 2. - С. 16-27.

2. Surgical repair of ventricular septal defect after myocardial infarction: outcomes from the Society of Thoracic Surgeons National Database / Arnaoutakis G. J., Zhao Y., George T. J. et al. // Ann. Thorac. Surg. - 2012. - Vol. 94 (2). - P. 436-443.

3. Postinfarction ventricular septal defect: right ventricular approach - the extended "sandwich" patch / Asai T.,
Hosoba S., Suzuki T., Kinoshita T. // Semin. Thorac. Cardiovasc. Surg. - 2012. - Vol. 24. - P. 59-62.

4. Ventricular septal rupture after acute myocardial infarction / Birnbaum Y., Fishbein C., Blanche C. et al. // N. Engl. J. Med. - 2002. - Vol. 347. - P. 1426-1432.

5. Risk factors of mortality after surgical correction of ventricular septal defect following myocardial infarction: Retrospective analysis and review of the literature / CingMars A., Voisine P., Dagenais F. et al. // Int. J. Cardiol. 2016. - Vol. 206. - P. 27-36.

6. Postinfarction ventricular septal rupture: repair by endocardial patch with infarct exclusion / David T. E., Dale L., Sun Z. // Thorac Cardiovasc. Surg. - 1995. Vol. 110. - P. 1315-1322.

7. Contemporary reperfusion therapy for cardiogenic shock: the GUSTO-I trial experience. The GUSTO-I Investigators. Global Utilization of Streptokinase and Tissue Plasminogen Activator for Occluded Coronary Arteries / Holmes D. R., Bates E. R., Kleiman N. S. et al. // J. Am. Coll. Cardiol. - 1995. - Vol. 26. - P. 668-674.

8. Mid-term results for the use of the extended sandwich patch technique through right ventriculotomy for postinfarction ventricular septal defects / Hosoba S., Asai T., Suzuki T. // Eur. J. Cardiothorac. Surg. - 2013. - Vol. 43. - P. e116e120.

9. Factors related to heart rupture in acute coronary syndromes in the Global Registry of Acute Coronary Events / LopezSendon J., Gurfinkel P., Lopez de Sa E. et al. // Eur. Heart J. - 2010. - Vol. 31. - P. 1449-1456.

10. Outcome and survival analysis of surgical repair of postinfarction ventricular septal rupture / Pang P. Y., Sin Y. K., Lim C. H. et al. // J. Cardiothorac. Surg. - 2013. Vol. 8. - P. 44-52.

11. Ventricular septal rupture complicating acute myocardial infarction: clinical characteristics and contemporary outcome / Poulsen S. H., Praestholm S., Munk K. et al. // Ann. Thorac. Surg. - 2008. - Vol. 85. - P. 1591-1596.

12. Long-term result safter surgical treatment of postinfarction ventricular septal rupture / Ruhparwar A., Karck M., Kallenbach K. et al. // Eur. J. Cardiothorac. Surg. 2015. - Vol. 47 (4). - P. 720-724.

13. A Post-infarction ventricular septal defect: risk factors and early outcomes / Serpytis P., Karvelyte N., Serpytis R. // Helelnic J. Cardiol. - 2015. - Vol. 56 (1). - P. 66-71.

\title{
Early surgical treatment of postinfarction ventricular septal rupture
}

\author{
Moroz V. S. ${ }^{1}$, Oryshchyn N. D. ${ }^{1,2}$, Pavlyk S. S. ${ }^{1}$, Kushta O. Y. ${ }^{1}$, Tytyuk V. A. ${ }^{1}$, Kurtyak Z. Z. ${ }^{1}$ \\ ${ }^{1}$ Lviv Regional State Clinical Centre of Cardiology \\ ${ }^{2}$ Danylo Halytskyj Lviv National Medical University
}

Ventricular septal rupture (VSR) is the cause of up to 5\% of deaths in the early period of myocardial infarction (MI). Surgical treatment of postinfarction VSR in the early period of MI is combined with a high risk, but can reduce the mortality rate of patients. MI.

Objective. To analyze the course of postinfarction VSR nd effectiveness of surgical treatment during the acute period of

Materials and methods. We performed surgical ventricular septal plasty for postinfarction VSR in acute period of MI in 5 patients of Lviv Regional Center of Cardiology. The diagnosis is established by echocardiography. Infarction exclusion technique (David) was used for the plasty. The time from the beginning to the IM to operations was from 1 to 5 days. One 
patient died of multiple organ failure, the other four have recovered, the follow-up is 11 to 36 months. In three patients we found residual shunt on the edge of the patch on the 1-2 day after operation, but it did not require reoperation.

Conclusions. Ventricular septal plasty in acute period of MI has positive results. Echocardiography is a diagnostic method for postinfarction VSR and for residual shunting.

Key words: myocardial infarction, ventricular septal rupture, echocardiography, septal plasty.

\title{
Ранняя хирургическая тактика при постинфарктных разрывах межжелудочковой перегородки
}

\author{
Мороз В. С. ${ }^{1}$, Орищин Н. Д. ${ }^{1,2}$, Павлик С. С. ${ }^{1}$, Кушта О. Ю. ${ }^{1}$, Титюк В. А. ${ }^{1}$, Куртяк 3. $3 .{ }^{1}$ \\ ${ }^{1}$ Львовский областной государственный клинический лечебно-диагностический кардиологический центр \\ 2 Львовський национальный медицинский университет имени Данила Галицкого
}

Разрывы межжелудочковой перегородки (МЖП) - причина до 5\% смертей в раннем периоде инфаркта миокарда (ИМ). Хирургическое лечение в раннем периоде сопряжено с повышенным риском, однако позволяет уменьшить смертность пациентов.

Цель работы - проанализировать течение послеинфарктного разрыва МЖП и эффективность хирургического лечения в остром периоде ИМ.

Материалы и методы. У 5 пациентов Львовского кардиологического центра в остром периоде ИМ выполнили пластику МЖП по поводу разрыва. Диагноз установлен методом эхокардиографии. Операцией выбора была пластика МЖП методом исключения инфаркта за David. Время от начала ИМ до операции составило от 1 до 5 суток. Один пациент умер вследствие полиорганной недостаточности, другие четверо выздоровели и находятся под наблюдением от 11 до 36 месяцев. В 3 случаях на 1-2-й день после операции у пациентов возникло резидуальное шунтирование по краю заплаты, которое не требовало реоперации.

Выводы. Пластика разрывов МЖП в остром периоде ИМ по методу David целесообразна и имеет позитивный результат. Эхокардиография - метод диагностики разрывов и резидуального шунтирования.

Ключевые слова: инфаркт миокарда, разрыв межжелудочковой перегородки, эхокардиография, пластика межжелудочковой перегородки. 